\title{
Studi Analisis dan Mitigasi Harmonisa pada PT. Semen Indonesia Pabrik Aceh
}

\author{
Stefanus Suryo Sumarno, Ontoseno Penangsang, Ni Ketut Aryani \\ Jurusan Teknik Elektro, Fakultas Teknologi Industri, Institut Teknologi Sepuluh Nopember (ITS) \\ Jl. Arief Rahman Hakim, Surabaya 60111 Indonesia \\ e-mail: stefanus_29@yahoo.com, ontosenop@ee.its.ac.id, ketut.aryani@gmail.com
}

\begin{abstract}
Abstrak-PT. Semen Indonesia merupakan salah satu perusahaan dalam negeri yang bergerak di bidang produksi semen. PT. Semen Indonesia sedang mendirikan pabrik baru di Aceh. PT. Semen Indonesia menggunakan motormotor induksi dalam proses produksi semen. Untuk mengendalikan kecepatan putaran motor-motor induksi tersebut diperlukan VFD (Variable Frequency Drive). VFD merupakan salah satu beban non linear sehingga penggunaanya akan menimbulkan munculnya harmonisa pada sistem kelistrikan di pabrik ini. Harmonisa jika dibiarkan terus-menerus akan menimbulkan masalah pada peralatan listrik lainnya seperti transformator, motor, dan kabel. Masalah-masalah tersebut pada akhirnya berujung pada kerugian ekonomi. Oleh karena itu perlu dilakukan studi harmonisa dan mitigasi untuk mengurangi harmonisa pada PT. Semen Indonesia Pabrik Aceh.

Mitigasi harmonisa dilakukan dengan pemasangan filter single tuned. Filter yang dipasang berhasil meredam harmonisa dan memperbaiki faktor daya. Nilai THD V dan THD I dibawah 5\%. Simulasi dan analisis dilakukan dengan menggunakan software ETAP 12.6.
\end{abstract}

Kata Kunci-kualitas daya, flicker, motor starting.

\section{PENDAhUluan}

$\mathrm{P}$ T. Semen Indonesia, perusahaan dalam negeri yang bergerak dalam bidang produksi semen, menggunakan motor-motor listrik dalam proses produksinya. Motor-motor listrik ini dapat dikendalikan kecepatannya dengan menggunakan VFD (Variable Frequency Drive). VFD merupakan salah satu beban non linear. Beban non linear adalah beban yang bentuk gelombang arus maupun tegangan keluarannya tidak sama dengan gelombang masukannya (mengalami distorsi). Beban non linear dapat mengakibatkan munculnya harmonisa. Harmonisa jika nilainya sudah diluar batas kewajaran dapat mempengaruhi sistem kelistrikan dan dapat menimbulkan masalah pada peralatan-peralatan listrik. Dampak harmonisa jika dibiarkan akan menimbulkan kerugian teknis dan finansial bagi pihak perusahaan.

Harmonisa tidak bisa dihilangkan secara keseluruhan, tetapi dapat diredam nilainya sampai berada dalam batas aman. Banyak cara yang bisa dilakukan untuk meredam harmonisa, tetapi yang paling sering dilakukan adalah dengan pemasangan filter pasif pada sistem kelistrikan. Sebelum merencanakan sebuah filter, terlebih dahulu kita harus melakukan studi harmonisa untuk mengetahui kondisi harmonisa di sistem kelistrikan tersebut. Pada tugas akhir ini dilakukan studi analisis dan mitigasi harmonisa menggunakan software ETAP 12.6. Mitigasi harmonisa dilakukan dengan menggunakan filter single tuned. Setelah mitigasi dilaksanakan, maka dilakukan pengecekan ulang kondisi harmonisa pada sistem.

\section{HARMONISA SISTEM TENAGA LISTRIK}

\section{A. Harmonisa Sistem Tenaga Listrik}

Harmonisa dalam sistem tenaga listrik dapat didefinisikan sebagai gelombang terdistorsi secara periodik pada keadaan steady state yang disebabkan oleh interaksi antara bentuk gelombang sinus sistem pada frekuensi fundamental dengan komponen gelombang lain yang merupakan frekuensi kelipatan integer dari frekuensi fundamental sumber. Bila gelombang dengan frekuensi kelipatan integer tersebut digabungkan dengan gelombang sinus dengan frekuensi sumber akan menghasilkan gelombang yang terdistorsi seperti Gambar 1.

Setiap orde harmonisa memiliki urutan fasa yaitu positif (+), negatif (-), dan nol (0) seperti yang diperlihatkan pada Tabel 1. Setiap urutan fasa harmonisa memiliki efek yang berbeda-beda. Urutan positif menimbulkan panas berlebih pada konduktor atau saluran. Urutan negatif menimbulkan torsi lawan pada motor listrik yang menyebabkan motor berlawanan arah putarnya. Urutan nol meningkatkan arus kontribusi pada kawat netral.

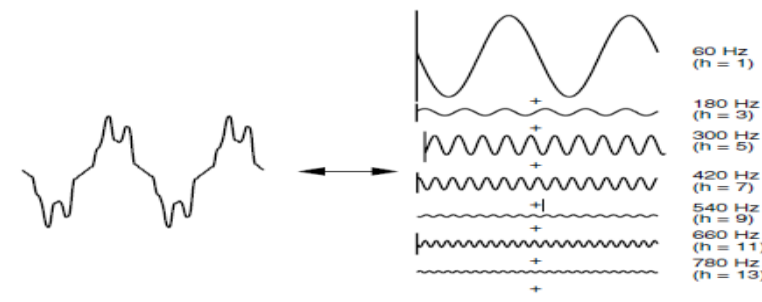

Gambar 1. Bentuk Gelombang yang Mengandung Harmonisa TABEL 1. URUTAN FASA HARMONISA

\begin{tabular}{ccc}
\hline \hline Orde Harmonisa & Frekuensi (Hz) & Urutan \\
\hline 1 & 50 & + \\
2 & 100 & - \\
3 & 150 & 0 \\
dst & dst & dst \\
\hline \hline
\end{tabular}

\section{B. Penyebab Harmonisa}

Harmonisa pada sistem tenaga listrik disebabkan oleh beban-beban non-linear. Beban non-linear yang dimaksud adalah peralatan elektronika daya yang menggunakan komponen semi-konduktor seperti mosfet, SCR, dan IGBT. Komponen semi-konduktor tersebut menghubungkan dan memutus (switching) arus sesuai dengan algorithma kontrol tertentu. Proses switching tersebut jarang berimpit dengan zero crossing dari gelombang sumber/supply; sehingga mengakibatkan timbulnya pulsa-pulsa arus. Pulsa-pulsa arus tersebut mengakibatkan timbulnya harmonisa sehingga walaupun tegangan sumber yang digunakan murni sinusoidal, arus yang dihasilkan akan berbentuk non-sinusoidal dan 
mengandung harmonisa. Ilustrasi beban non-linear penyebab harmonisa dapat dilihat pada Gambar 2.

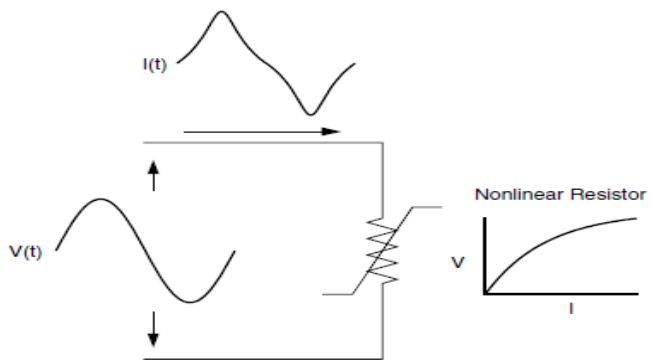

Gambar 2. Harmonisa yang disebabkan oleh Beban Non Linear

\section{Sumber-Sumber Harmonisa di Industri}

Sumber harmonisa pada industri adalah beban nonlinear yang meliputi :

1. Konverter 3 fasa

2. Tanur busur

3. Transformator

4. Motor Induksi

\section{Tegangan dan Arus Harmonisa}

Pada dasarnya beban non-linear adalah sumber dari arus harmonisa pada sistem tenaga. Arus harmonisa ini akan mengalir melalui jaringan sistem sehingga akan menimbulkan tegangan harmonisa seperti ilustrasi pada Gambar 3.

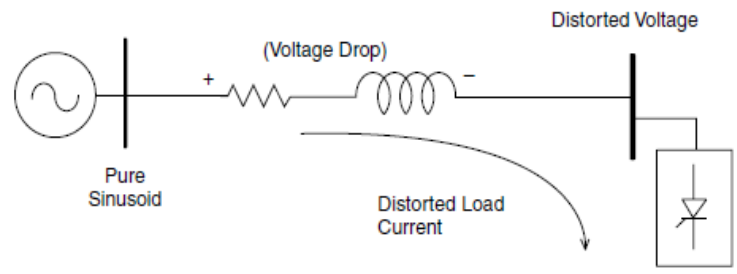

Gambar 3. Arus Harmonisa Menimbulkan Tegangan Harmonisa

\section{E. Pengaruh Harmonisa}

Harmonisa dapat menimbulkan dampak buruk bagi peralatan-peralatan listrik lainnya seperti transformator, motor, relay pengaman, dan penghantar atau kabel. Berikut ini adalah pengaruh harmonisa pada beberapa peralatan.

Pada Mesin-Mesin Berputar, Harmonisa mengakibatkan rugi pada belitan stator, rangkaian rotor, dan laminasi pada stator dan rotor meningkat. Rugi-rugi pada konduktor stator dan rotor lebih besar daripada rugi-rugi yang disebabkan resistansi DC karena arus Eddy atau efek kulit.

Pada Transformator, Arus Harmonisa meningkatkan rugi-rugi histerisis dan arus Eddy serta tekanan isolasi. Arus harmonisa juga meningkatkan rugi-rugi tembaga. Arus beban yang mengandung harmonisa akan mengakibatkan transformator mengalami panas yang berlebih. Pada transformator daya terdapat arus sirkulasi harmonisa ketiga urutan nol pada belitan delta. Sirkulasi arus yang berlebihan dapat melampaui batas kemampuan belitan sehingga dapat merusak belitan transformator.

Ketika resonansi seri dan pararel antara kapasitor dan sistem dapat terjadi, tegangan dan arus akan mengalami kenaikan, sehingga meningkatkan rugi-rugi yang tinggi dan panas berlebih pada kapasitor yang sering menjadi penyebab kerusakan kapasitor bank.

\section{F. Indeks Harmonisa}

Sinyal harmonisa memiliki sifat distrukstif terhadap sinyal fundamental serta nilai RMS sinyal secara keseluruhan. Besarnya gangguan dari harmonisa terhadap sinyal fundamental dinotasikan dalam bentuk Prosentase Total Harmonic Distortion (THD). Nilai THD dapat dihitung menggunakan rumus :

$$
T H D=\frac{\sqrt{\sum_{2}^{K} U n^{2}}}{U 1} \times 100 \%
$$

Keterangan:

$\mathrm{K}$ = Komponen harmonisa maksimum

Un = Komponen harmonisa yang diamati

$\mathrm{U} 1=$ Komponen fundamental

THD memiliki standar nilai yang dapat dilihat pada IEEE 519-1992 seperti pada Tabel 2 dan Tabel 3.

TABEL 2. BATAS Distorsi TEgANGAN BERDASARKAN IEEE STD 5191992

\begin{tabular}{|l|c|c|}
\hline $\begin{array}{c}\text { Tegangan Saluran pada } \\
\text { PCC }\end{array}$ & $\begin{array}{c}\text { Distorsi Tegangan Individu } \\
(\%)\end{array}$ & $\begin{array}{c}\text { Jumlah Distorsi Tegangan } \\
\text { THD }(\%)\end{array}$ \\
\hline 69 KV dan di bawahnya & 3,0 & 5,0 \\
$69.000,1$ sampai $161 \mathrm{kV}$ & 1,5 & 2,5 \\
$161.000,1$ dan di atasnya & 1,0 & 1,5 \\
\hline
\end{tabular}

TABEL 3. BATAS Distorsi ARUS BERDASARKAN IEEE STD 519-1992

\begin{tabular}{|c|c|c|c|c|c|c|}
\hline \multicolumn{7}{|c|}{ Distorsi Harmonik Maksimum Arus dalam Persen dari $\boldsymbol{I}_{\mathbf{L}}$} \\
\hline $\boldsymbol{I}_{\boldsymbol{S} \boldsymbol{C}} \boldsymbol{I}_{\mathbf{L}}$ & $<11$ & $11 \leq h<17$ & $17 \leq h<23$ & $\mathbf{2 3} \leq \boldsymbol{h}<35$ & $\leq 35$ & TDD \\
\hline$<20^{*}$ & 4,0 & 2,0 & 1,5 & 0,6 & 0,3 & 5,0 \\
$20<50$ & 7,0 & 3,5 & 2,5 & 1,0 & 0,5 & 8,0 \\
$50<100$ & 10,0 & 4,5 & 4,0 & 1,5 & 0,7 & 12,0 \\
$100<1000$ & 12,0 & 5,5 & 5,0 & 2,0 & 1,0 & 15,0 \\
$>1000$ & 15,0 & 7,0 & 6,0 & 2,5 & 1,4 & 20,0 \\
\hline
\end{tabular}

Keterangan :

PCC = Titik antara ujung dari pengguna dengan sistem

peralatan dimana pelanggan lain dilayani.

$\mathrm{I}_{\mathrm{SC}} \quad=$ Arus hubung singkat pada PCC.

$\mathrm{I}_{\mathrm{L}} \quad=$ Arus Beban Maksimum pada PCC.

TDD $=$ Total Demand Distortion

\section{G. Resonansi}

Resonansi terjadi ketika nilai reaktansi induktif sama dengan nilai reaktansi kapasitif $(\mathrm{XL}=\mathrm{XC})$. Kapasitor bank yang dipasang untuk memperbaiki faktor daya dapat menimbulkan resonansi sistem yang diikuti dengan naiknya arus yang sangat besar yang merugikan kapasitor bank tersebut. Terdapat dua jenis resonansi pada sistem, yaitu resonansi paralel dan seri.

Resonansi paralel dapat terjadi ketika sebuah kapasitor bank dipasang di bus yang sama dengan sumber harmonisa yang bersifat induktif. Resonansi paralel menghasilkan impedansi yang tinggi pada busbar saat frekuensi resonansi. Impedansi yang tinggi pada busbar akan mengakibatkan busbar mengalami tegangan lebih atau overvoltage. Gambar 4 adalah Sistem dengan resonansi paralel.

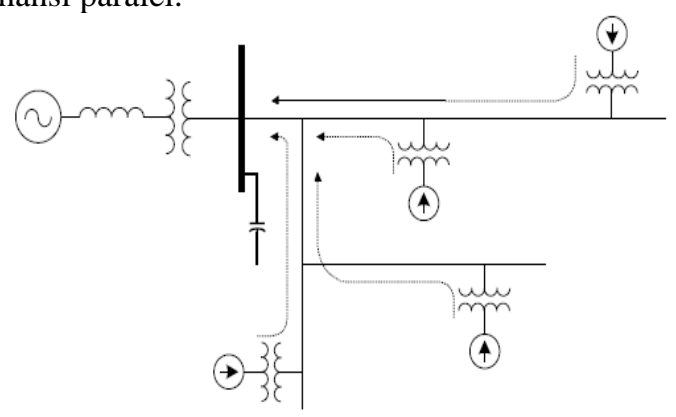

Gambar 4. Sistem Dengan Resonansi Paralel

Resonansi seri terjadi ketika reaktansi kapasitor bank membentuk rangkaian seri dengan sumber harmonisa seperti pada Gambar 5. Resonansi seri dapat menurunkan 
nilai impedansi pada kapasitor. Pada saat merancang sebuah filter harmonisa, diibaratkan yang terjadi adalah resonansi seri. Pada saat frekuensi resonansi nilai impedansi turun, sehingga arus harmonisa pada frekuensi tersebut mengalir kearah filter. Karena arus harmonisa diserap oleh filter, maka harmonisa yang ada pada bus akan berkurang atau dengan kata lain mengalami peredaman. Gambar 6 menunjukan respon frekuensi sistem ketika mengalami resonansi.

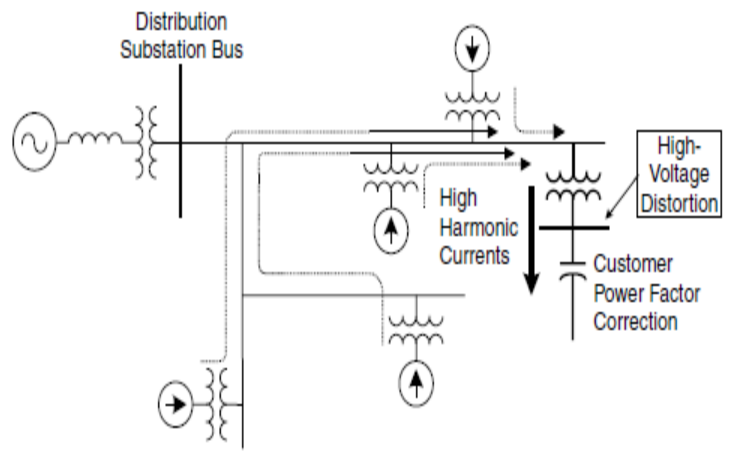

Gambar 5. Sistem Dengan Resonansi Seri

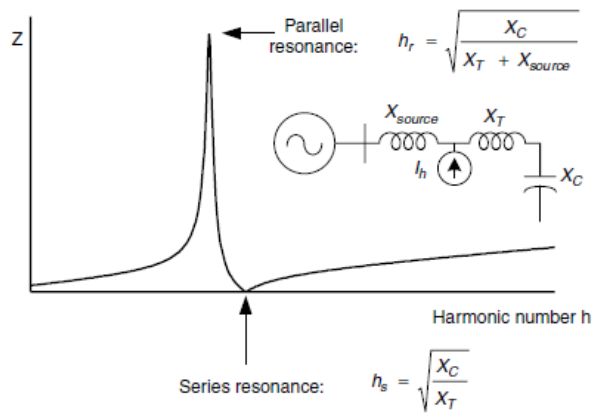

Gambar 6. Respon Frekuensi Sistem ketika terjadi Resonansi

\section{H. Mitigasi Harmonisa}

armonisa pada sistem kelistrikan sering timbul di industri. Harmonisa ini harus dikendalikan sebelum menjadi masalah dan berdampak pada peralatan listrik lainnya. Jika harmonisa telah menjadi masalah, maka hal-hal yang dapat dilakukan adalah :

1. Mengurangi arus harmonisa yang ditimbulkan beban.

2. Menambahkan filter harmonisa pada sistem kelistrikan.

3. Modifikasi respon frekuensi sistem.

\section{VFD (Variable Frequency Drive)}

VFD adalah peralatan elektronika daya yang digunakan untuk mengatur kecepatan putaran motor. VFD terdiri dari konverter 3 fasa, seperti yang dijelaskan di sub bab sebelumnya bahwa VFD adalah salah satu sumber harmonisa. VFD banyak digunakan di PT. Semen Indonesia Pabrik Aceh dan pada tugas akhir ini harmonisa yang di bahas adalah harmonisa yang timbul dari VFD.

Cara kerja VFD adalah mengubah tegangan AC 3 fasa dari sisi input menjadi tegangan DC dengan menggunakan rectifier 3 fasa. Tegangan DC tersebut kemudian akan disalurkan ke inverter 3 fasa untuk diubah menjadi tegangan AC 3 fasa dengan frekuensi yang bisa kita atur sesuai kebutuhan. Contoh rangkaian VFD dapat dilihat pada Gambar 7.

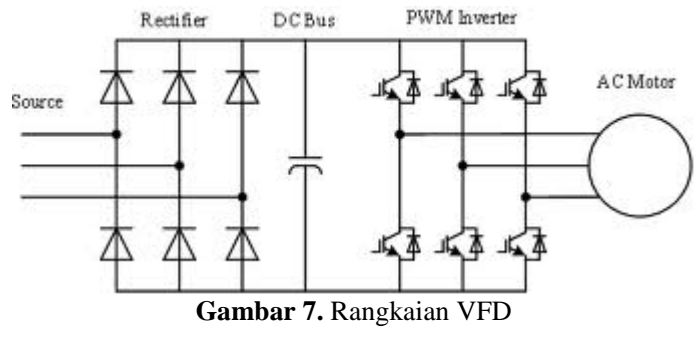

\section{J. Single Tuned Filter}

Salah satu cara mitigasi harmonisa adalah dngan menggunakan filter pasif. Filter pasif terdiri dari elemen induktansi, kapasitansi, dan resistansi. Elemen induktansi dan kapasitansi dari filter pasif dirancang untuk beresonansi pada frekuensi tertentu yang biasa kita sebut frekuensi resonansi. Sehingga apabila ada harmonisa dengan frekuensi yang sama dengan frekuensi resonansi, maka filter pasif akan menyerap harmonisa tersebut, sehingga harmonisa tersebut tidak masuk ke sistem atau setidaknya aman bagi sistem. Filter pasif juga dapat digunakan untuk mengkompensasi daya reaktif dan memperbaiki faktor daya.

Single tuned filter adalah filter pasif yang ditala pada salah satu orde harmonisa (biasanya pada orde harmonisa rendah). Filter ini terdiri dari rangkaian seri kapasitor, reaktor dan resistor (RLC) seperti yang terlihat pada Gambar 8. Rangkaian filter ini mempunyai impedansi yang rendah pada frekuensi resonansinya. Sebuah shunt filter dikatakan ditala pada sebuah frekuensi, jika pada frekuensi tersebut reaktansi induktif dan kapasitifnya sama dengan nol $(\mathrm{XL}=\mathrm{XC})$. Kualitas sebuah filter $(\mathrm{Q})$ ditentukan dari ketajaman pada penalaannya. Filter dengan Q yang tinggi ditala secara tajam pada satu frekuensi harmonisa yang rendah (contohnya orde 5) dan nilai Q yang umum untuk filter jenis ini antara 30 dan 60 .

Faktor kualitas (Q) filter merupakan perbandingan antara induktansi (atau kapasitansi) pada saat resonansi dengan besarnya resistansi.

$$
Q=\frac{X_{0}}{R}
$$

Dimana $\mathrm{XL}=\mathrm{XC}=\mathrm{X} 0$ pada saat resonansi.

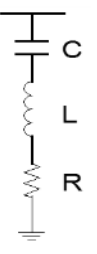

Gambar 8. Rangkaian Single Tuned Filter

\section{SiSTEM KELISTRIKAN PT. SEMEN INDONESIA PABRIK ACEH}

\section{A. Sistem Kelistrikan PT. Semen Indonesia Pabrik Aceh}

PT. Semen Indonesia adalah perusahaan yang bergerak di bidang industri produksi semen. PT. Semen Indonesia telah berkembang pesat dan saat ini telah mengembangkan perusahaanya dengan membangun pabrik-pabrik baru di beberapa wilayah di Indonesia salah satunya adalah Aceh. Sistem kelistrikan di Pabrik Aceh ini berada dalam masa perencanaan dan direncanakan dapat menanggung beban kurang lebih 45 MVA dengan menggunakan sumber listrik dari PLN pada tegangan $150 \mathrm{kV}$. Tabel 3.1 menunjukkan besarnya daya yang disuplai PLN untuk PT. Semen Indonesia Pabrik Aceh. 


\section{B. Sumber Harmonisa PT. Semen Indonesia Pabrik Aceh}

Pada umumnya sumber harmonisa pada sebuah pabrik adalah beban non-linear. Seperti yang dijelaskan pada sub bab sebelumnya bahwa beberapa motor di pabrik ini menggunakan VFD sebagai pengatur kecepatan, sehingga VFD inilah yang menjadi sumber utama harmonisa pada PT. Semen Indonesia Pabrik Aceh. Selain digunakan untuk mengatur kecepatan putaran motor VFD juga berfungsi untuk mengatasi arus starting motor yang nilainya terlalu tinggi. VFD menggunakan komponen elektronika daya yang dapat mengatur variasi frekuensi input ke motor induksi, sehingga putaran motor induksi dapat berubah-ubah. Single line diagram PT. Semen Indonesia Pabrik Aceh dapat dilihat pada Gambar 9.

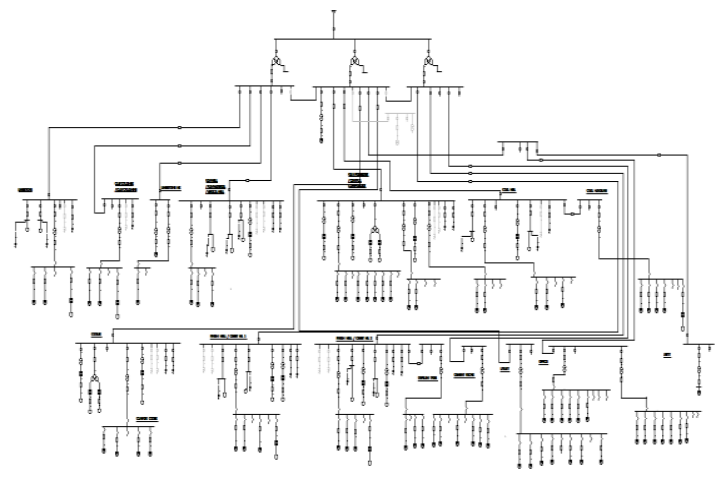

Gambar 9. Single Line Diagram PT. Semen Indonesia pabrik Aceh

C. Langkah-Langkah Peredaman Harmonisa pada PT. Semen Indonesia Pabrik Aceh

Tujuan yang ingin dicapai dari tugas akhir ini adalah mempelajari kondisi harmonisa pada sistem kelistrikan PT. Semen Indonesia Pabrik Aceh dan melakukan mitigasi harmonisa. Studi analisis dilakukan dengan pemodelan dan simulasi menggunakan software ETAP 12.6. Gambar 10 menunjukkan flowchart metodologi peredaman harmonisa pada sistem kelistrikan PT. Semen Indonesia Pabrik Aceh.

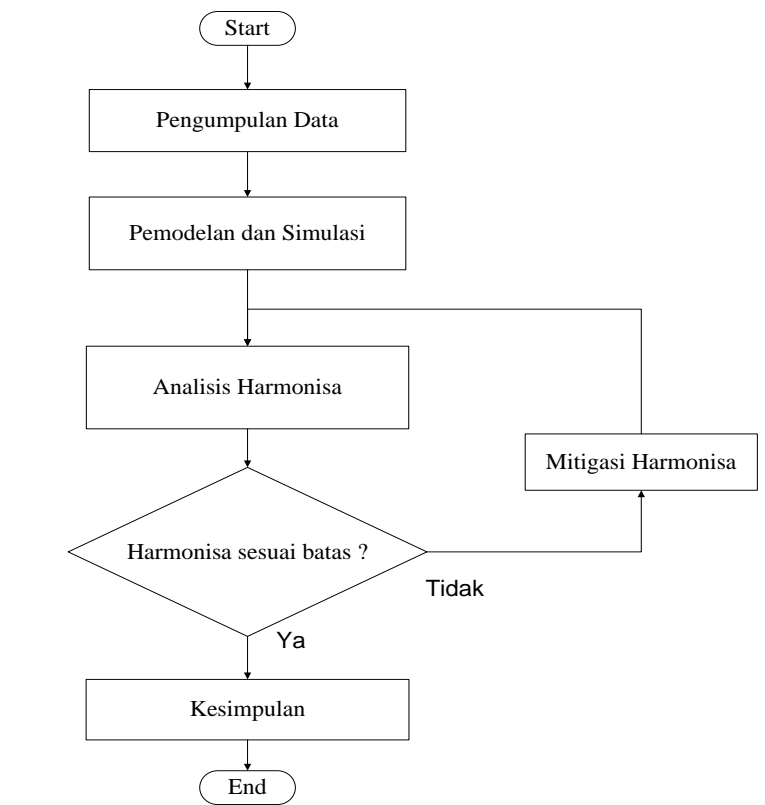

Gambar 10. Flowchart Metodologi Peredaman Harmonisa pada PT. Semen Indonesia Pabrik Aceh.

Metodologi yang digunakan pada penelitian tugas akhir ini adalah sebagai berikut:
1. Pengumpulan Data

Pengumpulan data-data sistem kelistrikan dan single line diagram dari PT. Semen Indonesia Pabrik Aceh.

2. Pemodelan dan Simulasi

Setelah semua data yang diperlukan untuk analisis harmonisa didapatkan, maka dilakukan pemodelan sistem dalam bentuk single line diagram menggunakan software ETAP 12.6. Kemudian dilakukan simulasi aliran daya dan harmonisa.

3. Analisis Harmonisa

Analisis harmonisa dilakukan untuk mengetahui nilai THD (Total Harmonic Distortion) pada sistem.

4. Mitigasi Harmonisa

Mitigasi harmonisa dilakukan dengan pemasangan filter pasif single tuned. Hasil analisis harmonisa dapat digunakan sebagai acuan untuk merancang filter.

5. Kesimpulan

Memberikan kesimpulan mengenai kondisi harmonisa pada sistem kelistrikan PT. Semen Indonesia Pabrik Aceh setelah mitigasi harmonisa dilakukan.

\section{SimULASI DAN ANALISIS}

\section{A. Kondisi Awal Sistem}

Kondisi awal sistem kelistrikan di pabrik ini adalah saat semua beban-beban meliputi motor induksi, VFD, lump terhubung ke sumber suplai dari PLN. Sebelum kita melakukan studi harmonisa pada pabrik ini, kita harus mengetahui kondisi aliran daya dari pabrik ini dengan melakukan simulasi. Simulasi aliran daya dilakukan untuk mengetahui nilai tegangan dan faktor daya di tiap bus. Hasil dari simulasi aliran daya tersebut dapat dilihat pada Tabel 4.

TABEL 4. Hasil SimUlasi AliRan Daya SiSTEM

\begin{tabular}{|c|c|c|c|c|}
\hline \multirow{2}{*}{ Bus } & \multicolumn{2}{|c|}{ Kondisi Awal } & \multicolumn{2}{|c|}{ Setelah Pemasangan Kapasitor Bank } \\
\hline & $\mathrm{kV}(\%)$ & PF (\%) & $\mathbf{k V}(\%)$ & PF $(\%)$ \\
\hline BUS PLN & 100 & 70,6 & 100 & 94,1 \\
\hline 821MV011 & 96,27 & 83,2 & 99,50 & 100 \\
\hline 821MV021 & 92,09 & 75,2 & 97,74 & 93,4 \\
\hline 821MV031 & 92,23 & 74,3 & 96,03 & 94,5 \\
\hline 831MV012 & 94,94 & 78,0 & 98,96 & -100 \\
\hline 831MV021 & 94,87 & 78,2 & 98,84 & $-92,6$ \\
\hline 831MV031 & 95,27 & 76,9 & 98,53 & 77 \\
\hline 831MV041 & 90,14 & 85,3 & 95,26 & 99,9 \\
\hline 831MV051 & 89,75 & 68,8 & 96,14 & 85,4 \\
\hline 831MV052 & 90,64 & 81,7 & 97,22 & $-98,4$ \\
\hline 831MV061 & 89,41 & 78,5 & 96,08 & 78,7 \\
\hline 831MV071 & 90,30 & 66,2 & 97,25 & $-99,6$ \\
\hline 831MV081 & 91,14 & 73,8 & 95,43 & 96,6 \\
\hline 831MV082 & 90,95 & 74,3 & 95,25 & 94,2 \\
\hline 831MV091 & 88,56 & 77,1 & 92,79 & 77,4 \\
\hline 831MV101 & 91,73 & 78,1 & 95,55 & 78,2 \\
\hline 831MV111 & 91,57 & 77,9 & 97,24 & 78,2 \\
\hline 831MV121 & 91,67 & 77,6 & 97,34 & 77,9 \\
\hline 831MV131 & 91,39 & 79,2 & 97,07 & 79,4 \\
\hline
\end{tabular}

Dari Tabel 4 diketahui bahwa banyak bus yang mengalami undervoltage dan nilai faktor dayanya rendah. 
Oleh karena itu perlu dipasang kapasitor bank sebagai kompensator daya reaktif dan untuk memperbaiki nilai tegangan yang ada di bus.

\section{B. Perancangan Kapasitor Bank}

Kapasitor bank akan diletakkan pada bus MV yang terdapat beban-beban motor induksi, karena pada bus tersebutlah yang nilai faktor dayanya kecil akibat beban motor yang bersifat induktif. Contoh Perhitungan nilai kapasitor bank adalah sebagai berikut:

Kapasitor Bank Bus 831MV012 (Limestone Crusher)

Faktor Daya Awal $\quad=78,0 \%$

$\mathrm{P}$ (Daya aktif) $\quad=1500 \mathrm{~kW}$

Pemasangan kapasitor agar mencapai faktor daya $98 \%$

Q1 $=1500 \tan (\operatorname{arc} \cos 0,78)=1500 \tan 38,74$

$=1213 \mathrm{kVAR}$

Q2 $=1500 \tan (\operatorname{arc} \cos 0,98)=1500 \tan 0,46$

$=12 \mathrm{kVAR}$

Maka Qc yang dipilih untuk memperbaiki adalah

$\mathrm{Qc}=\mathrm{Q} 1-\mathrm{Q} 2=1213-12=1201 \mathrm{Kvar}$

Dipasang kapasitor bank dengan nilai 1200 kVAR dibus 831MV012. Lokasi dan nilai daya reaktif kapasitor bank yang terpasang di sistem dapat dilihat pada Tabel 5 .

\begin{tabular}{cc} 
TABEL 5. KAPASITOR BANK PADA SISTEM \\
\hline \hline Bus & Daya Reaktif (kVAR) \\
\hline 831 MV012 & 1200 \\
831MV021 & 1200 \\
831MV041 & 4350 \\
831MV051 & 4000 \\
831MV052 & 2700 \\
831MV071 & 4000 \\
831MV081 & 4000 \\
831MV082 & 4000 \\
\hline
\end{tabular}

Dapat dilihat pada Tabel 4 bahwa setelah kapasitor bank dipasang pada sistem, tegangan di tiap bus tidak lagi mengalami undervoltage dan nilai faktor daya sistem mengalami kenaikan.

\section{Harmonisa Sistem Setelah Pemasangan Kapasitor Bank}

Simulasi harmonisa dilakukan untuk mengetahui kondisi harmonisa sistem setelah kapasitor bank dipasang. Hasil simulasi harmonisa dapat dilihat pada Tabel 6.

Tabel 6. Hasil Simulasi Harmonisa Setelah Pemasangan KAPASITOR BANK

\begin{tabular}{|c|c|c|c|c|}
\hline Bus & $\begin{array}{c}\text { THD V } \\
(\%)\end{array}$ & $\frac{\text { Standar IEEE }}{\% \text { THD V }}$ & $\begin{array}{c}\text { THD I } \\
(\%)\end{array}$ & $\frac{\text { Standar IEEE }}{\% \text { TDD }}$ \\
\hline 831MV012 & 0,90 & 5 & 10,77 & 8 \\
\hline $831 \mathrm{MV} 051$ & 6,43 & 5 & 13,67 & 5 \\
\hline 831MV052 & 10,38 & 5 & 78,13 & 8 \\
\hline 831MV061 & 10,36 & 5 & 6,23 & 8 \\
\hline $831 \mathrm{MV} 071$ & 2,30 & 5 & 22,29 & 5 \\
\hline
\end{tabular}

\section{Perancangan Single Tuned Filter}

Dari Tabel 6 diketahui bahwa nilai THD V dan THD I di beberapa bus melebihi standar yang diijinkan. Oleh karena itu akan dirancang single tuned filter untuk meredam harmonisa pada sistem. Single tuned filter akan digunakan untuk menggantikan kapasitor bank yang sebelumnya dipasang pada sistem karena Single tuned filter dapat berperan sebagai kompensator daya reaktif dan peredam harmonisa. Berikut ini contoh perhitungannya:

Design filter Bus 831MV012 (Limestone Crusher)
Single tuned orde 5, frekuensi tuning $(\omega n)=250 \mathrm{~Hz}$ Kapasitor (C)

$$
C=\frac{k V A R}{V l-l^{2} \times \omega 0}=\frac{1200}{6,3^{2} \times 2 \times 3,14 \times 50}=96,29 u F
$$

Induktor $(\mathrm{L})$

$$
\begin{aligned}
& L=\frac{1}{\omega n^{2} \times C}=\frac{1}{(2 \times 3,14 \times 250)^{2} \times 96,29 \times 10^{-6}} \\
& =4,21 \mathrm{mH} \\
& X L=\omega 0 \times L=2 \times 3,14 \times 50 \times 4,21 \times 10^{-3}=1,32 \Omega \\
& X O=X L=1,32 \Omega
\end{aligned}
$$

Resistor (R)

$$
R=\frac{X 0}{Q}=\frac{1,32}{45}=0,029 \Omega
$$

Lokasi dan nilai parameter single tuned filter yang terpasang pada sistem dapat dilihat pada Tabel 7.

\begin{tabular}{ccccc}
\multicolumn{4}{c}{ TABEL 7. SINGLE TUNED FILTER PADA SISTEM } \\
\hline \hline Bus & $\mathbf{C}(\boldsymbol{\mu} \mathbf{F})$ & $\mathbf{L}(\mathbf{m H})$ & $\mathbf{R}(\boldsymbol{\Omega})$ & Orde \\
\hline 831MV012 & 96.29 & 4.21 & 0.0290 & 5 \\
831MV021 & 96.29 & 2.15 & 0.0150 & 7 \\
831MV041 & 164.81 & 2.46 & 0.0170 & 5 \\
831MV041 & 184.06 & 0,45 & 0.0030 & 11 \\
831MV051 & 112.60 & 0.74 & 0.0050 & 11 \\
831MV051 & 208.20 & 0.29 & 0.0020 & 13 \\
831MV052 & 216.54 & 0.39 & 0.0027 & 11 \\
831MV071 & 237.47 & 0.35 & 0.0024 & 11 \\
831MV071 & 83.33 & 0.72 & 0.0051 & 13 \\
831MV081 & 115.81 & 3.50 & 0.0244 & 5 \\
831MV081 & 204.99 & 1.01 & 0.0071 & 7 \\
831MV082 & 143.40 & 0.58 & 0.0040 & 11 \\
831MV082 & 177.40 & 0.34 & 0.0024 & 13 \\
\hline \hline
\end{tabular}

E. Harmonisa Sistem Setelah Pemasangan Single Tuned Filter

Dari Hasil simulasi harmonisa pada Tabel 8 diketahui bahwa nilai THD $\mathrm{V}$ dan THD I mengalami penurunan yang drastis, Nilai THD V dan THD I Bus 831MV012, 831MV051, 831MV052, 831MV061, dan 831MV071 yang sebelumnya berada diluar standar, sekarang dibawah standar atau bisa dikatakan dalam kategori aman. Terbukti bahwa single tuned filter berhasil meredam harmonisa sistem kelistrikan PT. Semen Indonesia Pabrik Aceh.

TAbel 8. Hasil Simulasi HaRmonisa Setelah Pemasangan SINGLE TUNED FILTER

\begin{tabular}{ccccc}
\hline \hline \multirow{2}{*}{ Bus } & THD V & Standar IEEE & THD I & Standar IEEE \\
& $(\boldsymbol{\%})$ & \% THD V & $(\boldsymbol{\%})$ & \% TDD \\
\hline 831MV012 & 0,20 & 5 & 1,67 & 8 \\
831MV051 & 0,50 & 5 & 0,38 & 5 \\
831MV052 & 0,16 & 5 & 1,12 & 8 \\
831MV061 & 0,20 & 5 & 3,23 & 12 \\
831MV071 & 0,34 & 5 & 1,01 & 8 \\
\hline \hline
\end{tabular}

\section{KESIMPULAN}

Setelah melakukan studi harmonisa pada sistem kelistrikan PT. Semen Indonesia Pabrik Aceh, dapat disimpulkan sebagai berikut :

1. Kondisi awal sistem sebelum terpasang kapasitor bank maupun filter sangat buruk.

2. Filter pasif single tuned yang dipasang berhasil berfungsi dengan baik sebagai kompensator daya reaktif dan sebagai peredam harmonisa. THD V Bus 
831MV051 dari 6,43\% menjadi $0,50 \%$. THD V Bus $831 \mathrm{MV} 052$ dari $10,38 \%$ menjadi $0,16 \%$. THD V Bus 831 MV051 dari $10,36 \%$ menjadi $0,20 \%$.

3. Kualitas daya sistem kelistrikan PT. Semen Indonesia Pabrik Aceh berada dalam kondisi yang baik, dari segi faktor daya, tegangan, dan harmonisa nya setelah dipasang filter single tuned. Nilai faktor daya sistem menjadi 94,1\%. Nilai THD V dan THD I di bus MV dibawah $5 \%$.

\section{DAFTAR PUSTAKA}

[1] IEEE Std. 519-1992. "IEEE Recommended Practices and Requirement for Harmonic Control in Electrical Power Systems."
[2] McGraw-Hill, "Electrical Power Systems Quality". Second Edition.

[3] Annisa Eka Marini Pujiantar. 2014. Perencanaan Filter Hybrid untuk Mengurangi Harmonisa pada PT. Semen Indonesia Pabrik Rembang. Tugas Akhir Institut Teknologi Sepuluh Nopember.

[4] Rahmat Septian Wijanarko. 2014. Penentuan Peralatan untuk Meredam Harmonisa Berdasarkan Jenis Sumber Harmonisa, Orde, dan Magnitude Harmonisa dengan Memperhitungkan Biaya Investasi di PT. Wilmar Nabati, Gresik. Tugas Akhir Institut Teknologi Sepuluh Nopember.

[5] Ardian Rizkytama. 2009. Perencanaan High Pass dan Single Tuned Filter Sebagai Filter Harmonisa pada Sistem Kelistrikan Tabang Coal Upgrading Plant (TCUP). Tugas Akhir Institut Teknologi Sepuluh Nopember.

[6] Mohamed Awadalla, Mohamed Omer, dan Ahmed Mohamed, "Single-Tuned Filter Design for Harmonic Mitigation and Optimization with Capacitor Banks", IEEE Journal, 2015 